\title{
Study of Potentials and Challenges in Unconventional Oil and Gas Industry: An Argentinian Case Study
}

\author{
Milagros Arengo Piragine ${ }^{1}$, Satya Shah ${ }^{1,}$, and Alec Coutroubis ${ }^{1}$ \\ ${ }^{1}$ Applied Engineering and Management, Faculty of Engineering and Science, University of Greenwich, UK
}

\begin{abstract}
The aim of this paper is to analyse literature studies towards the potential of Vaca Muerta Field in the Neuquén Basin, its current development situation and the country's and Oil \& Gas Industry background. Argentina is the second largest country in South America, which highly depends on its service and agricultural industries, been one of the major exporters of beef and soybean products. Strongly dependent on hydrocarbons, which account for $86.1 \%$ of its energy consumption, the country lost energy self-sufficiency in 2007 , when it became a net importer of oil and gas. Concerns around the world about future shortages of energy were partially alleviated by the developments of commercially feasible techniques to extract oil and gas from unconventional resources, which are hard to extract due to the low porosity of the generating rock. Argentina turned to be the third and fourth larger holder of technically recoverable unconventional gas and oil respectively, mainly in the Neuquén Basin, were the second largest unconventional formation worldwide is located: Vaca Muerta is considered a world class resource, especially for its size, hydrocarbons content and thickness. It has been developed for seven years, achieving increasing production of oil and gas and improvements regarding costs, time and resources invested. As a conclusion, Argentina has vast and high-quality hydrocarbon reserves, what represents a huge opportunity for the country to recover energy self-sufficiency and its exporter position. New technologies and techniques are improving times and costs involved in the extraction of unconventional hydrocarbons in the country. In addition, the new government is taking action to improve reliability and encourage investments. All these should enhance Vaca Muerta's development.
\end{abstract}

\section{Introduction}

"Before the middle of the past decade, the availability of crude oil and energy was an increasingly limiting factor in the global economy. The increase in the demand for energy was rising at an average annual rate of $2.2 \%$ ", and there was a belief that by 2050 energy supply would not be enough to fulfil the projected demand" [1]. This was an important concern for Argentina, as hydrocarbons represent $86.1 \%$ of the country's Energy Matrix, out of which $50.2 \%$ corresponds to natural gas. In the past, Argentina was an oil and gas self-sufficient country, even exporting gas surplus to neighbouring countries. Currently, the country became a net importer of oil and gas, spending around US\$35 billion annually between imports and subsidies [1].

The existence of unconventional resources worldwide - shale gas, tight gas, shale oil and tight oil-have been known for decades, but it was difficult and economically inviable to extract them. The development of new technology, mainly horizontal drilling and high-pressure hydrocarbon fracking, has made commercial production possible in U.S. shale oil and gas formations. After U.S. developments, the energy industry started looking for other unconventional reserves throughout the world. According to EIA/ARI World Shale Gas and Shale Oil Resource Assessment [2], Argentina has 22.7 Trillion cubic meters $(\mathrm{Tm} 3)$ of technically recoverable shale gas resources ( $8.7 \mathrm{Tm} 3$ only in Vaca Muerta); the world's third largest resource behind only US and China; and 27 billion barrels (BBL) of unconventional oil reserves (16.2 BBL in Vaca Muerta), ranking fourth in the world behind Russia, US and China.

"With both the trade balance and national budget affected as the gap between production and consumption has widened", unconventional reserves could reverse the sector trends [3]. Vaca Muerta Formation in Neuquén Basin plays an important role for this aim, having distinctive geological qualities, such as thickness and depth, areal extent, organic content and thermal maturity. Additionally, as the formation was already active with conventional extraction, most of the infrastructure needed for unconventional activity is already in place [4]. The aim of this paper is to conduct an early aspect of literature studies to understand the potential of Vaca Muerta Field in the Neuquén Basin, its current development situation and the country and industry background. The authors aim to present recent literature findings within the topic and towards the background of Argentina's energy efficiency and that towards relying on more recoverable unconventional gal and oil source as form of energy supplies. The paper also presents an early start for any future studies carried out within this context for researchers and practitioners within this research area.

$\overline{{ }^{a} \text { Corresponding author: s.shah@gre.ac.uk }}$ 


\section{Literature Review}

The review of the literature aims to focus towards developing firstly the understanding of the Argentina's energy and gas sector across the region and that of its usage in the past two decades. The authors also aim to examine literature evidence towards the use of unconventional forms of oil and gas application and its advantages within the region. Through the help of the literature evidence, the authors will further determine the importance of the market allowing detailed investigation within the research topic for future studies.

\subsection{Overview of Argentina's Profile}

The Republic of Argentina (Republic Argentina) is the second largest country in South America regarding its size as well as its economy. The country's 2,780,400 km2 are divided in 23 provinces and an autonomous city, Ciudad Autónoma de Buenos Aires (CABA), and populated by more than 44 million inhabitants. According to Gomes \& Brandt [5], Argentina's strategic position, between the Pacific and Atlantic Oceans, allows the country to control "vital trade routes in the southern hemisphere, i.e. Strait of Magellan, Beagle Channel, and the Drake Passage". The country is a member of the Mercosur trade zone, along with Brazil, Paraguay and Uruguay. According to the International Monetary Fund (IMF) [6], Argentina's GDP in 2017 was estimated in USD 546.3 billion, 2.8\% over 2016 figures. Two thirds of Argentina's GDP are originated in the service sector, which has grown steadily in the last decade. The remaining contribution is originated in the agricultural and industry sector. Argentina is one of the largest beef and soybean exporters "and is a leading producer of sunflower seeds, yerba mate (an infusion that resembles tea), lemons and soybean oil" [5]. In this way, natural resources are of great importance for the country.

Argentina's last severe crisis was in 2001/2002, “when the government decided to unpeg the national currency (Argentine Peso) from the US dollar" [5]. A slow recovery followed, fuelled by higher commodity prices and consumption encouraging policies. After a decade of economic recovery, in 2014 the US Supreme Court supported the judgement of the Appeal Court of New York "in favour of holdout funds which did not adhere to the renegotiation of Argentina's bonds", which resulted in foreign investors loss of confidence and lack of access to international capital markets [5]. In conjunction with a slowdown in Chinese and Brazilian imports from Argentina, the country's economy saw a deep weakening. In December 2015, government changed and President Mauricio Macri started taking actions with the aim of restoring integrity and transparency in public sector operations [6]. Macri's policies included the abolishment of currency controls, expansion of financial opportunities for companies, rise of energy and transportation tariffs, lift of capital controls and elimination of repatriation and trade restrictions [7]. As a result of the new government actions and plans, the country returned to the global financial markets. As a proof of the slight recovery of foreign reliability, Argentina was able to sell USD 16.5 billion of sovereign debt in April 2016. Although the economy is improving and investors are becoming more interested in the country, there is still certain scepticism. "Argentina continues to battle high inflation, a depreciating currency, low commodity prices and low demand" [5].

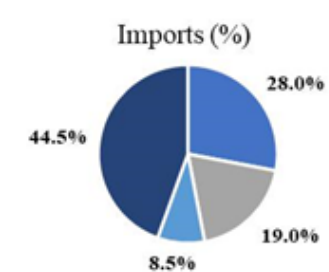

- Machines, instruments and electric materials

- Transport, equipment

= Oil, refined products \& gas

= Others

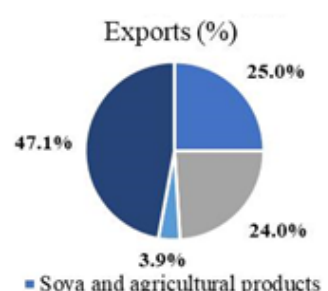

- Soya and agricultural products = Foodstuff, beverages and tobacco = Fuels and energy - Others
Figure 1. Argentina's Main Imports and Exports in 2016 [8]

According to the Argentinian National Institute of Statistics and Censuses (INDEC) [8], Argentina imported USD 56 billion in goods and services in 2016. As shown in Fig. 1, the country's top imports are Machines, instruments and electric materials, Transport equipment and Oil, Refined Products \& Gas. The country also exported in 2016 USD 58 billion in goods and services, most of them Soya and Agricultural Products, Foodstuff, beverages and tobacco and Fuels \& Energy.

\subsection{Argentina's Energy Sector}

Argentina's Energy Matrix is mostly integrated by hydrocarbons, accounting for $86.1 \%$ of the country's energy consumption. This dominance has prevailed for more than 50 years, with a slightly decrease from $89 \%$ in 1980 to the current figure. It is possible to see in Fig. 2 that natural gas increased its share from $27 \%$ in 1980 to $50.2 \%$, displacing oil as the main source of energy [5]. During these years, oil absolute values remained steady, whereas natural gas values and share grew in tandem with energy demand and production, mostly due to industrial and residential consumption growth [5].

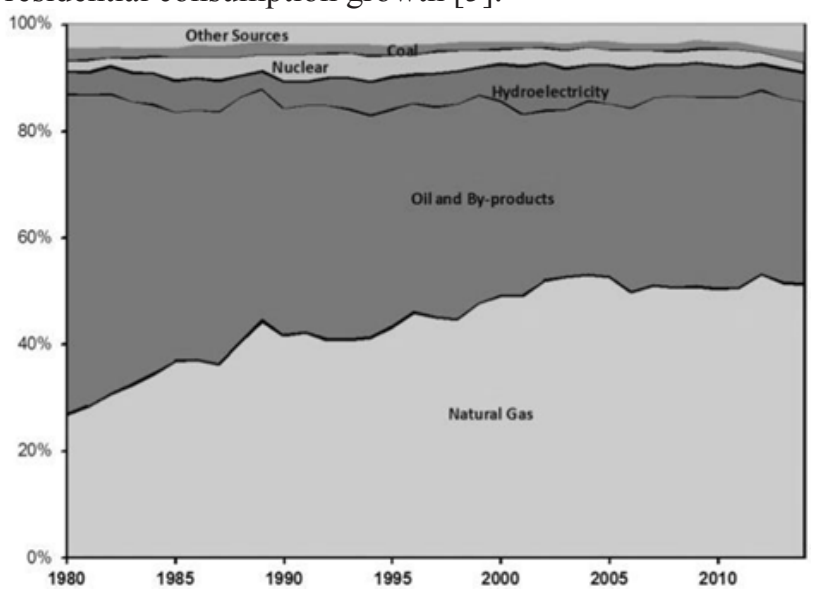

Figure 2. Argentina's Energy Matrix Evolution 1980-2016 [5]

Today, natural gas accounts for $50.2 \%$ of Argentina's power, followed by oil and hydroelectricity, accounting for $35.9 \%$ and $9.8 \%$ respectively. Just $0.8 \%$ of the country's power is obtained by renewable sources [3]. 


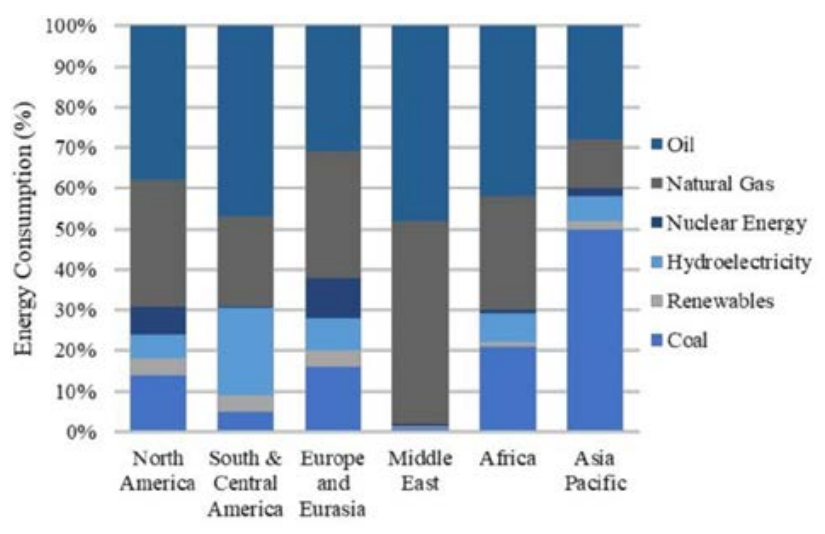

Figure 3. Energy Matrix Composition by Region in 2016 [10]

Compared to average consumption in other regions in Fig. 3 , the consumption of hydrocarbons is higher than the rest of the world, except the Middle East [10]. The difference is mainly in natural gas, whereas Argentina is similar to other countries regarding oil consumption. It is also necessary to emphasize the difference in coal consumptions between Argentina and the rest of the world; whereas the consumption of this fuel averages 28\% globally, in Argentina its participation in the Energy Matrix is minimal. The same happens with hydroelectricity, although at a lower extent. As a result, and until renewables and other sources of energy are developed, oil and gas are crucial for the country's economy, and it is necessary to develop plans and actions for hydrocarbons strategic development.

\section{Hydrocarbon resources in Argentina}

According to Gomes \& Brandt [5], although Argentina has 24 sedimentary basins, hydrocarbon is produced in just five of them, whereas the other 19 are known to present high geological risk: Noroeste, Cuyana, Neuquina (Neuquén), San Jorge and Austral. Around 67,000 exploration and production wells were drilled in these five basins over more than 100 years.

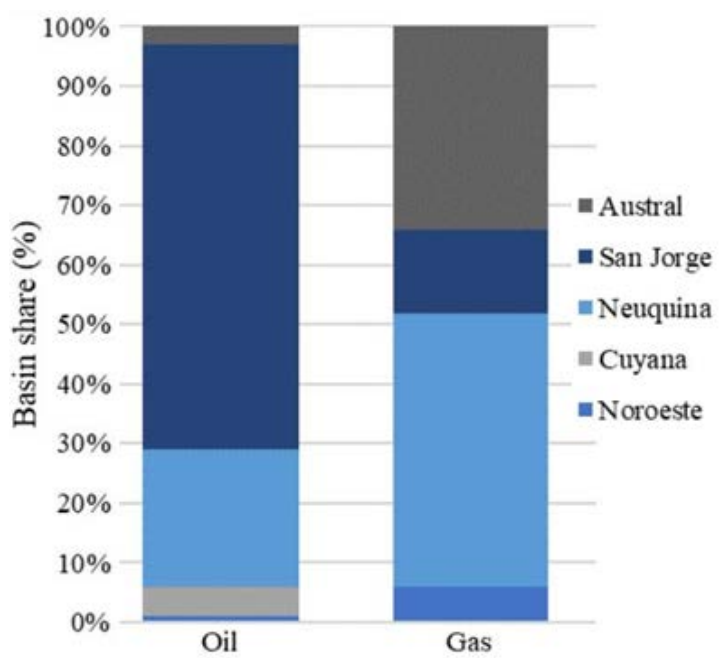

Figure 4. Proved Oil and Gas Reserves by Basin in 2016 [10]

Fig. 4 presents Argentina's proved oil and gas reserves by basin as at 2016, according to the country's Ministry of Energy and Mining [11]. Oil proved reserves totalled 2.4
BBL, being San Jorge Basin were most of the proved reserves are, accounting for $68 \%$ of the total, followed by Neuquina with $23 \%$. Regarding natural gas, proved reserves totaled $0.4 \mathrm{Tm} 3$, being Neuquina Basin were most of the proved reserves are, accounting for $46 \%$ of total reserves, followed by Austral with 34\%. As it is possible to read in Fig. 4, the Neuquina Basin is and has been for several years the core of Argentina's oil and gas industry. However, Sanagua [9] explains that most of the basins, including Neuquina, have been exploited for several years and have already reached their maturity stage. This means most of their recoverable reserves have already been produced. As a result, oil production in the country has been decreasing since 1998, with the Neuquén Basin production declining around $7 \%$ on average since 2002 . One thing to consider is that the oil extracted from San Jorge Basin (Escalate) and Neuquén Basin (Medanito) are different and therefore differ in price. The Medanito is the lighter one and the easiest to refine, which makes it more expensive, usually USD 2-4 more than Escalate's price.

\section{Crude oil price}

Argentina's oil prices depend on the International price of crude oil, as well as the exchange rate of the Argentinian Peso (\$) regarding the US dollar. Consequently, in order to understand the evolution of Argentina's energy industry in the last 7 years, it is important to mention how international oil prices behaved. According to Hough \& Barton [12], in 2011 oil prices averaged USD 100-110, due mainly to political matters in the Middle East and Libya. These prices remained stable during the two subsequent years, fueled by prosper economic scenarios and strong demand from China and US. However, the second half of 2014 saw a plunge in oil prices, as a result of oversupply and a slowdown in demand and global economic growth. Moreover, US shale production has contributed to the excess of oil supply.

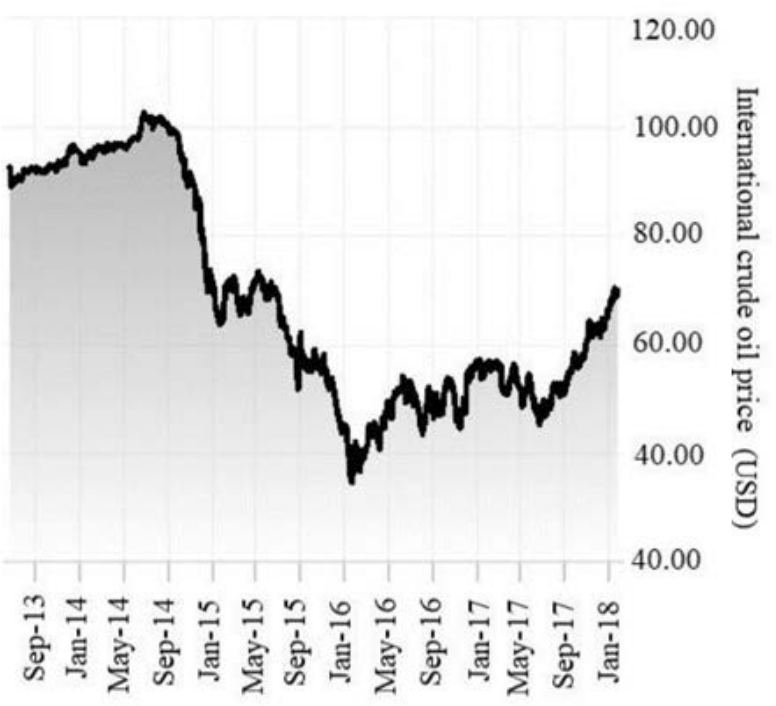

Figure 5. International Crude Oil Price Evolution (2013-18) [13]

Prices continued falling in 2015, when the Organization of Petroleum Exporting Countries (OPEC) declined to cut its output to rebalance the market, and oil prices reached a twelve-year trough by January 2016, with Brent and WTI 
trading at USD 34. As shown in Fig. 5, in 2016 oil prices started a slow recovery, mainly due to OPEC producers cutting output. Furthermore, lower oil production in US, disruptions in Libya, Venezuela and Nigeria and a strong growth in global demand contributed as well [13]. While OPEC applies strict caps on supply, USA and Russia are also contributing to the oil prices recovery, reaching in this way a two-year high, trading at USD 63 (WTI)/USD 68 (Brent) at the beginning of 2018 .

\section{How Argentina became an energy importer}

After the economic crisis in 2001/2002 mentioned before, the Argentinian government started the application of policies of pricing control for oil, gas and refined products, mainly in order to guarantee domestic supply and encourage consumption as a means for economic recovery [4]. Policies included export taxes for crude oil at $25 \% / 45 \%$, which left upstream oil companies no other choice rather than supplying the local market. In this way, internal prices 'decoupled' from international ones. The policies were successful in the short-term, as an increase in demand was achieved fuelled by lower prices, and therefore GDP grew at an average 4\% between 2002 and 2010. However, the actions also affected the level of investment in the Oil \& Gas Industry upstream sector, since prices were not competitive. Indeed, there was a sharp decline in exploration and production investment as a result of low local prices, while international ones became stronger. On the contrary, consumption has been increasing as a result of low prices and subsidies. In this way, increasing interventionism from the government, artificial energy pricing and increasing subsidies in the demand and supply side [5], led to an imbalance between local supply and demand for hydrocarbons, as can be seen in Fig. 6. Therefore, Argentina has had to import gas, diesel and gasoline at international prices [4].

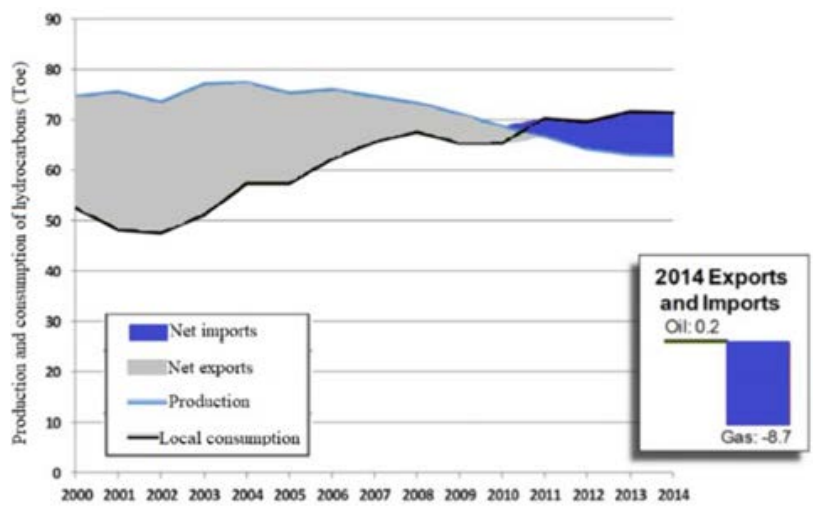

Figure 6. Production and Consumption of Hydrocarbons in Tonne of Oil Equivalent [4]

According to BP Statistical Review of World Energy 2017 [10], Argentina produced 619 thousand barrels per day (Kbpd) of oil in 2016, a 27\% decrease on 2006 levels. In contrast, consumption has increased by $45 \%$ to $687 \mathrm{Kbpd}$. As regards natural gas, Argentina produced 38.3 billion cubic meters per day (Bm3pd) in 2016, a 17\% decrease on 2006 levels, while consumption has increased by $19 \%$ to 49.6 Bm3pd. As a result, Argentina's energy imports have been increasing in the last 10 years, causing an important deficit in the commercial balance for those goods.

\section{The special case of natural gas}

As mentioned previously, Natural Gas accounts for 50.2\% of the country's energy consumption, which makes it worth it to pay special attention to this good. The discovery in 1997 of the Loma la Lata (LLL) deposit with around 0.4 Tm3 [9], was followed by a significant expansion of the trunk gas pipeline capacity, growth in penetration of the residential market, and development of Compressed Natural Gas (CNG) for vehicles, the replacement of most liquid fuels in the industrial sector and the construction of several export pipelines to Chile, Brazil and Bolivia [5], giving more importance and share to this source of energy. LLL reached a peak in 2004, accounting for around 20\% of the national production of gas, before reaching its maturity stage and starting its decline.

However, demand remained in a steady growth, encouraged by governmental policies mentioned in the previous section after the $2001 / 2002$ crisis, in conjunction with subsidies. Residential prices have remained at very low levels around \$0.5-0.6/million British thermal units (MMBtu) since 2002, with oil companies obliged to supply to this segment [4]. In 2007, the country finished its export role, and started importing natural gas, mainly from Bolivia and LNG. According to BP [6], Argentina imported $5.2 \mathrm{Bm} 3$ of $\mathrm{LNG}$ by tankers and $6.1 \mathrm{Bm} 3$ by pipeline in 2016.

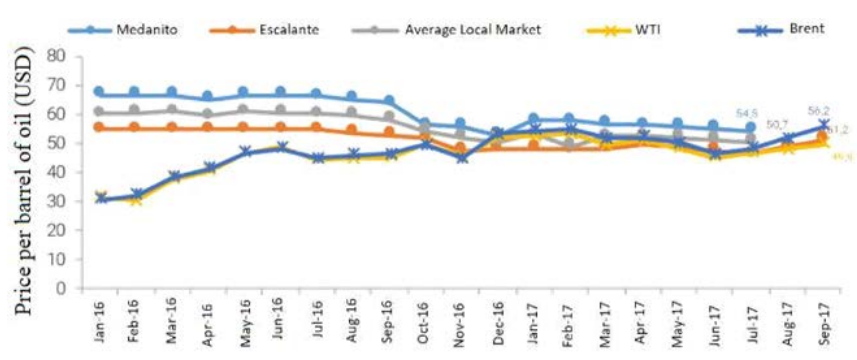

Figure 7. International and Local Oil Price (2016/17) [14]

\section{Efforts made to improve the scenario}

With both the trade balance and national budget affected by the energy supply and demand imbalance, some actions were applied to improve the situation:

- In order to reverse the investment decline in the upstream sector, the first action was to maintain local oil prices high after the international price plunged in 2014/2015.

- Some incentive programs were designed to encourage the production of natural gas, such as "Gas Plus" and "Plan Gas", that set maximum prices of 5.2 and 7.5 USD/MMBtu, respectively, which were higher than international ones [5].

- Increase in gas and electricity end-user tariffs, with the aim of reducing subsidies from the differential between local and international prices and reorient them towards low income segments. 
In 2017, however, as international oil prices recovered substantially, local oil prices started a 'coupling' process towards international ones, as can be seen in Fig. 7, allowing local prices to be ruled by free market and with the aim of increasing foreign investor's interest in the industry. The government has also announced gas prices couple for 2021, when gas plans end [14].

\subsection{Unconventional Oil and Gas}

"Before the middle of the past decade, the availability of crude oil and energy was an increasingly limiting factor in the global economy". Demand for energy was increasing at an average $2.2 \%$ per annum [1], and energy supply was not enough to satisfy this demand for many years. As a result, international efforts started to focus on renewables. By 2005, huge technological developments transformed the supply perspective. From the application of new concepts of characterization of the subsoil and technology in the construction and completion of the wells, the industry began to migrate towards the exploration and exploitation of non-traditional reservoirs, which we now know as unconventional, among which are include tight and shale, both in oil and gas [9]. Although the existence of unconventional resources has been known internationally for many years, US was the first country capable of commercially produce unconventional hydrocarbons, by the development of horizontal drilling and fracking.

According to Sánchez \& Ramírez Martínez [15], unconventional resources are normally found in heterogeneous geological systems, extremely complex, and often little studied and/or characterized. One of the most important characteristics is the very low permeability of the rock, as they are stored in the rocks that generated them. As a result, it is more difficult to make them flow from the rock, and a combination of technology and techniques are required to extract them than that used in more conventional deposits. This is why they are called 'unconventional' [1]. Generally, unconventional reservoirs must meet a series of requirements that make them economically viable: Organic Composition, Thermal Maturity, Thickness and areal extension, Adsorption Capacity (mainly in Shale Gas), Fracturability, Overpressure, Depth and Surface installations [7].

To extract oil and gas from the rock, it is necessary to stimulate it by a method called 'Fracking', also known as hydraulic fracturing, shown in Fig. 8. According to Sierra [16], this technique injects a water mixture, agent of support and chemical additives at high pressure to fracture the rock. The most commonly used proppant is sand due to its low cost. The aim of the sand is to move into the fissures and keep them open in order to artificially allow oil and gas to flow to the surface.

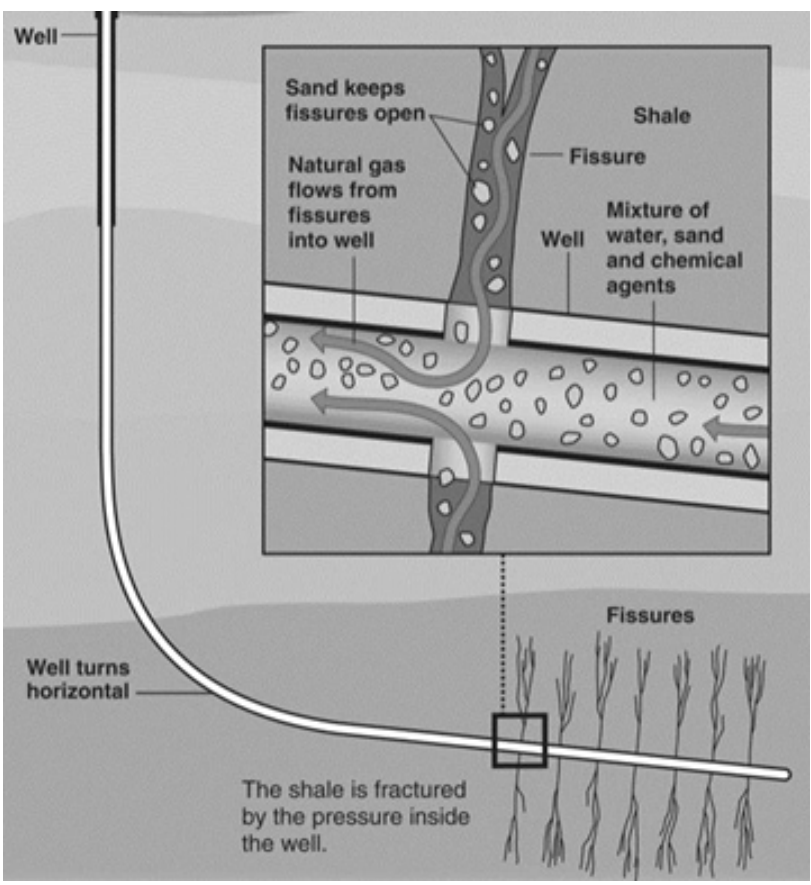

Figure 8. Example of Hydraulic Fracking for Gas Production [16]

Hydraulic stimulation has been used in more than 2 million wells around the world in the last century [17], and has become very popular for conventional and unconventional production. However, oil and gas production from unconventional reservoirs differ from conventional production. Some of the key differences are the use of larger quantities of water, the need of large-volume fractures and shorter life cycles, since the rates of production decline is higher for unconventional reservoirs, which makes it necessary to drill more wells.

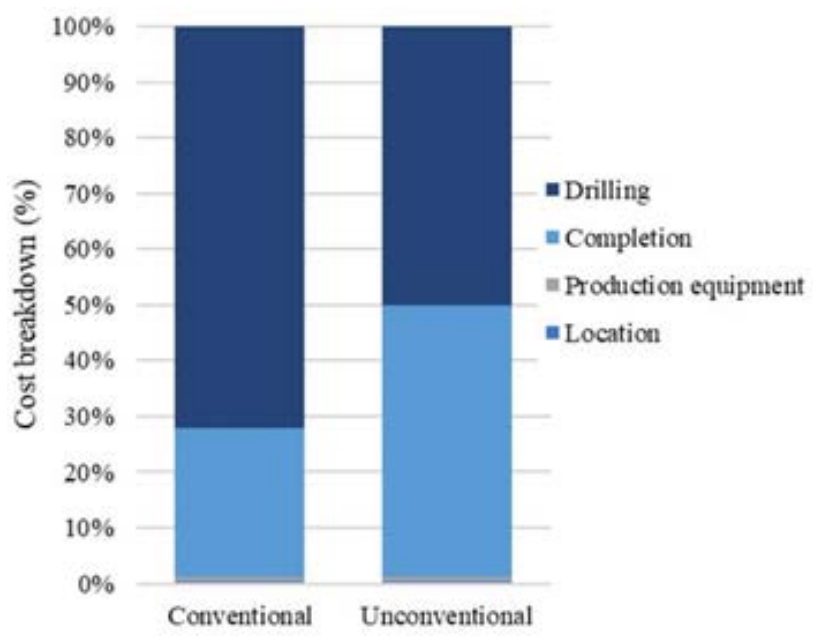

Figure 9. Typical Cost Breakdown for Conventional vs. Unconventional Wells [4]

On the other hand, the heterogeneity of the unconventional reservoirs is such that practically no two analogous reservoirs exist. Therefore, the investment required in its characterization is much higher than that of conventional reservoirs, especially in its initial stage; hence the need to develop pilots to identify the techniques to be applied to make the development of each reservoir more efficient 
[18]. As a result, CAPEX is greater for unconventional reservoirs. Fig. 9 shows how costs are distributed in conventional and unconventional wells. In unconventional wells, completion is as important as drilling regarding costs [4]. Following the Shale Boom in US, unconventional resources called the attention of investors all over the world. This is how Repsol, the Spanish company that held $98 \%$ of YPF's shares, started looking for unconventional resources and discovered $0.13 \mathrm{Tm} 3$ of tight gas in Neuquén. Sometime later, the U.S Energy Information Administration [2] published a report where it estimated that Argentina had $22.7 \mathrm{Tm} 3$ of technically recoverable shale gas resources, the third largest globally, behind China and the U.S, and could supply about 400 years. The same report said that the country also had 27 BBL of technically recoverable oil, the fourth largest figure globally, after Russia, US and China (Fig. 10). According to Gomes \& Brandt [5], the main sedimentary basins where is possible to find shale formations in Argentina are shown in Fig. 11:

- Neuquén basin: This is the heart of shale exploration in the country, where the main potential is found in Los Molles and Vaca Muerta.

- San Jorge basin: Located in the Patagonian region, especially in the Province of Chubut.

- Austral-Magallanes basin: Located in the south of the country

- Paraná basin: Located in north-east of Argentina

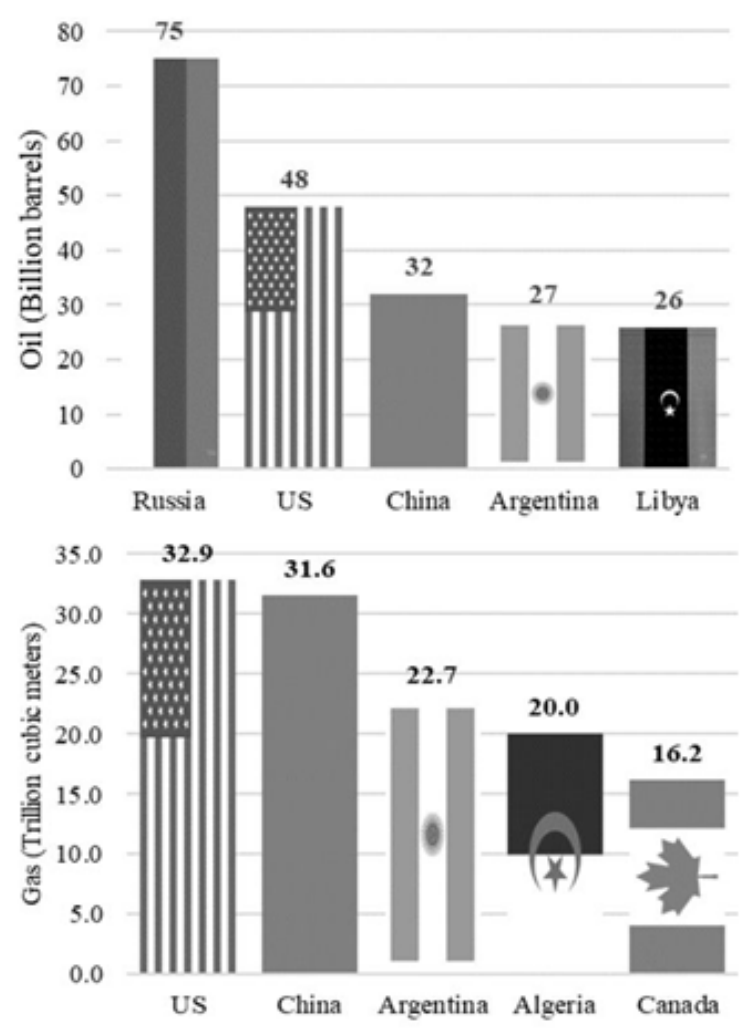

Figure 10. Est. Technically Recoverable Shale Resources [2]

Argentina is one of the four countries in the world that develops its shale resources [19]. The country produces both shale gas and shale oil, as well as tight gas, mostly in the Vaca Muerta Formation in the Neuquén Basin.

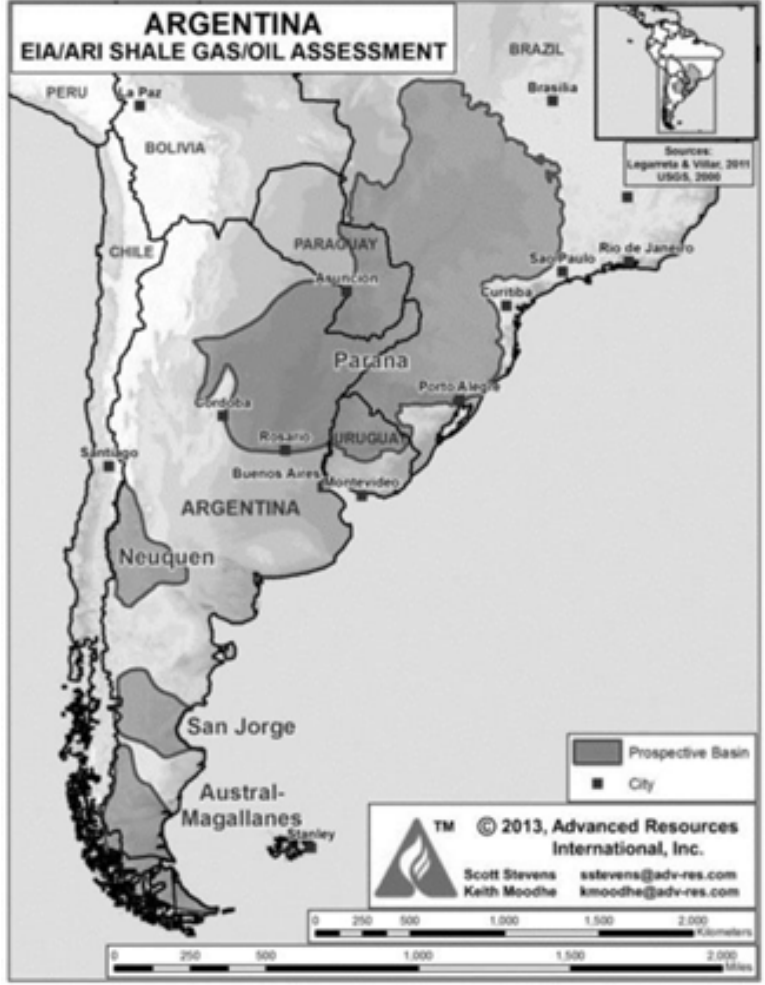

Figure 11. Unconventional Resources in Argentina [5]
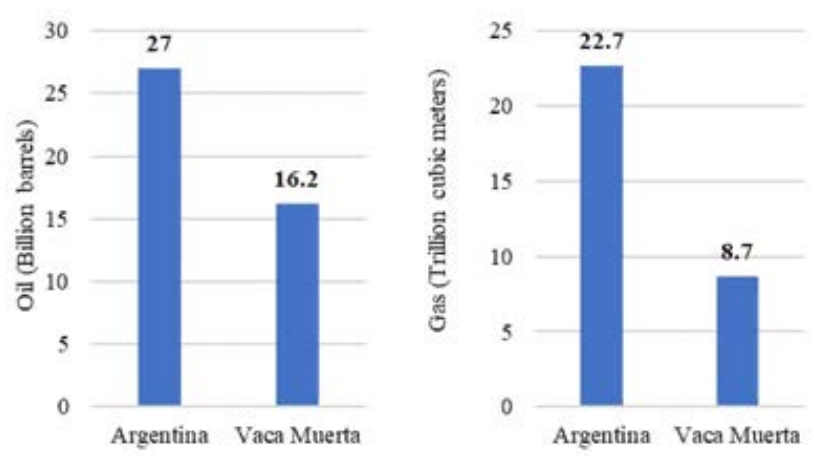

Figure 12. Technically Recoverable Resources in Argentina and Vaca Muerta

\subsection{Neuquén Basin and Vaca Muerta}

The Neuquén Basin is located in the central-west of Argentina, limiting with the Andes Mountains, occupying $66,900 \mathrm{~km} 2$ and including parts of the La Pampa, Mendoza, Neuquén, and Rio Negro provinces. It is considered to be the most significant basin of the country, producing almost $50 \%$ of the domestic gas supply [16]. The Vaca Muerta formation is the primary source rock for hydrocarbons in the Neuquén basin, and the second largest shale formation worldwide [3], covering $30,000 \mathrm{~km} 2$ and holding $60 \%$ and $38 \%$ of technically recoverable oil and gas in Argentina respectively, as can be seen in Fig. 12 The map in Fig. 13 shows the areas with tight oil, wet and dry gas formations in the Neuquén basin. The eastern and southern regions in the basin have potential for oil production; the western region is predominately dry gas whereas the rest contains wet gas and condensate [5]. Vaca 
Muerta is known for being a 'World-class resource'. According to Leite \& Sobreira [4], "the formation stands for its thickness, depth, areal extent, organic content, depositional environment, mineralogy, pressure and thermal maturity". Its thickness is the most important characteristic; being it between 180 and 600 meters, it allows drilling vertical and horizontal wells, reducing costs and environmental implications. However, the geologic characteristics of Vaca Muerta vary significantly depending on depth and location.

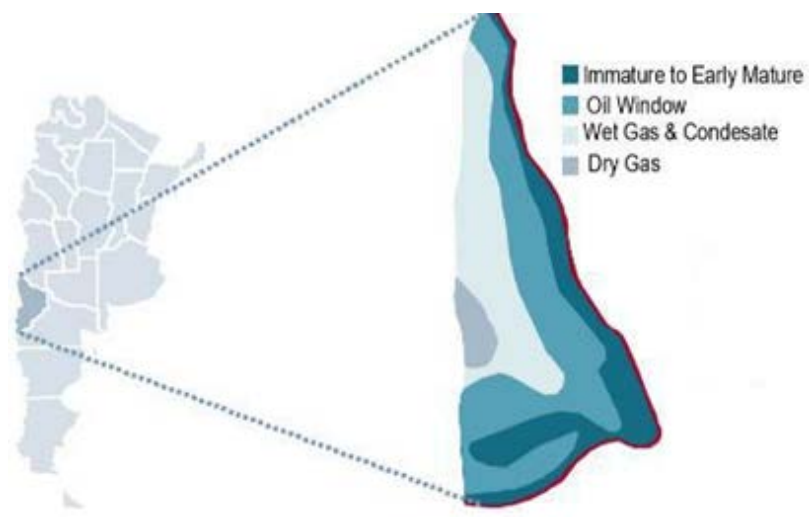

Figure 13. Thermal Maturity Scheme Vaca Muerta Formation [5]

"Vaca Muerta is the most developed shale play outside North America and has attracted over 9 billion USD in capital investments since 2010 to drill nearly 800 wells in the play" [20]. Production in the field started in 2012 with the drilling of 28 vertical wells in Loma la Lata, obtaining encouraging results. One of the strong characteristics of the Neuquén Basin is that shale resources are found in the same places as conventional resources, but at a greater depth. Consequently, the basic infrastructure is already available, which reduces costs and therefore makes the development more economically feasible.

Once Vaca Muerta's capacity to produce oil and gas was proven, the challenge became to make the activity profitable. That is, produce more oil and gas from each well at a lower cost [19]. According to Letcher \& Strada [21] this was sought by the implementation of two techniques:

- Horizontal drilling: The aim is to expose a larger area of the reservoir to the well drilled to increase its productivity.

- Series drilling Factory model: Consists in the incorporation of special equipment that does not require assembly and disassembly to move from one well to another ("walking rigs" or walking teams), resulting in a lower on average drilling times.

Fig. 14 and Fig. 15 show the evolution of oil and gas production in Vaca Muerta along with the number of wells drilled, where it is possible to see that despite the decrease in the number of new wells drilled between 2015 and 2016, and the production continued its growing trend. This results from the increase in productivity due to the combined effect of horizontal drilling with the factory model development. The area of greatest development of Vaca Muerta is Loma Campana, which includes Loma La Lata. In this area $70 \%$ of the wells and $76 \%$ of the oil production are concentrated, over an area of approximately $230 \mathrm{~km} 2$ [19].

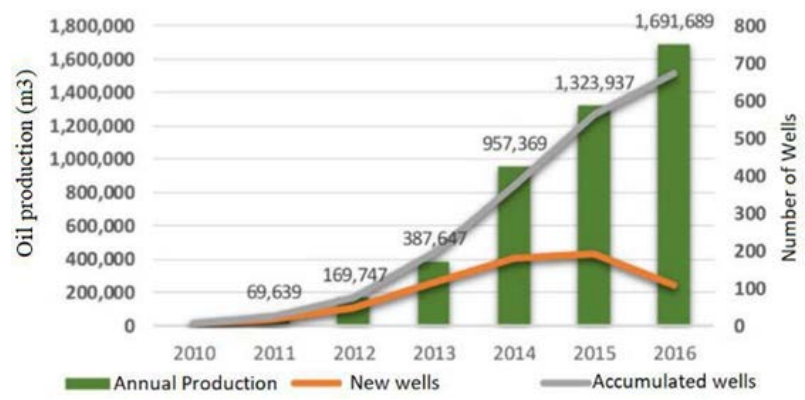

Figure 14. Yearly Oil Production vs. No. of Drilled Wells in Vaca Muerta [19]

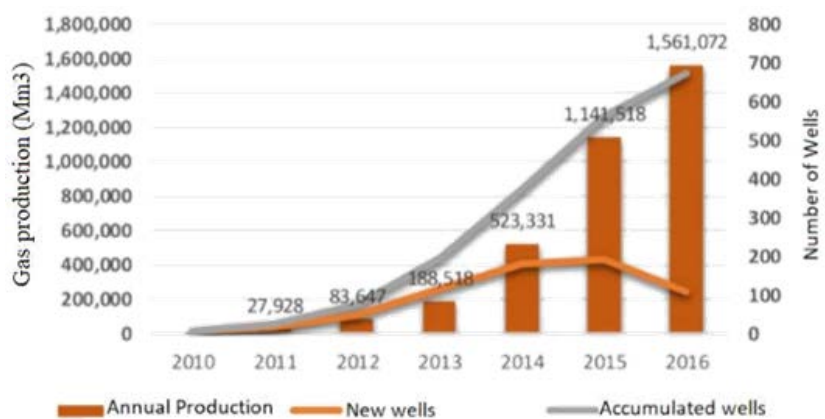

Figure 15. Yearly Gas Production vs. No of Drilled Wells [19]

According to Sierra [16], from the beginning of operations at Vaca Muerta, oil and gas production increased every month. "Month to month growth was approximately 13\% and $17 \%$ for oil and gas production, respectively. Over $90 \%$ of the active production wells in the Vaca Muerta formation have been in operation since 2013".

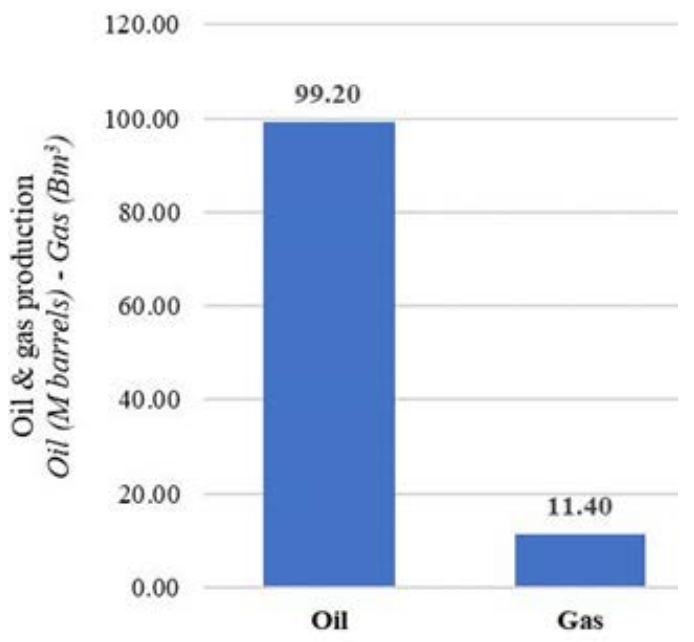

Figure 16. Accumulated Oil \& Gas Production in Vaca Muerta in June 2017 [22]

After seven years of development, 734 wells have been drilled and production as of June 2017 was 37,296 bpd 
$(5,929 \mathrm{~m} 3 / \mathrm{d})$ of oil and $5.94 \mathrm{Mm} 3 \mathrm{pd}$ of gas representing $8 \%$ of the total oil produced in the country and $5 \%$ of the national gas production [19], reaching accumulated production since 2010 of 99.2 million barrels and 11.4 $\mathrm{Bm} 3$ for oil and gas respectively, as shown in Fig. 16 [22]. It is worth to mention that the greatest activity in recent years was for the production of oil due to the high prices in previous years. However, investors are currently paying more attention to the development of the gas zone, considering the new price scenarios and the deficit that the country presents. The increase in activity generated learning that allowed to lower the drilling times and consequently the costs. Drilling times have decreased and the average of the wells drilled in 2017 was 31 days. The record in Vaca Muerta corresponds to the well LLL-1281 (h) drilled in just 17 days [19]. "However, development of the area has stalled in recent years, with a complex regulatory framework and high labour costs cited as reasons slowing investor participation" [3]. Since January 2017 , the country's reliability seemed to have improved, as new joint ventures were agreed for the exploration and production in Vaca Muerta, especially in the gas window. Currently, well performance and gas prices are encouraging the entrance of foreign investments. YPF S.A. is an Oil \& Gas company with most of its shares held by the Argentine Government. It has been through privatization (1999) and renationalization (2012) processes in the last 20 years. The company operates 52\% of the Argentine refineries, as well as holding around 57\% of the liquid fuel market share. Furthermore, it holds $42 \%$ of the acreage in Vaca Muerta $(12,000 \mathrm{~km} 2)$, being the most important player in the field. "YPF is the company that has invested the most, and therefore knows the most, about the Vaca Muerta formation" [1].

\section{Conclusions}

Argentina is a large country with vast natural resources. Considering the availability of hydrocarbons, either conventional or unconventional, the country could not only recover its self-sufficiency, but also its position as net exporter of oil and gas. Actions are taking place for this aim, not only in the over-ground, with the new government trying to 'fix' previous actions that led the country to the current imbalance between supply and demand, and consequently, affected the national budget and reserves. Also, local and foreign operators, led by YPF, are implementing new technologies and techniques to reduce times and cost in unconventional production. There is no doubt about the potential of Vaca Muerta, considering the quality of the resources it allocates, its thickness and thermal maturity. However, it needs to be developed and investment is needed for that sake. The authors of this research study aimed to investigate the different forms of hydrocarbon reserves that represents huge opportunities for the country to enable the recovery of self-sufficiency and export position of their energy supply. New technologies and techniques are improving times and costs involved in the extraction of unconventional hydrocarbons in the country.

\section{References}

[1] R. O. Parisi, "Shale Resources in Argentina: The Vaca Muerta Shale Formation. A technical, economic and political analysis," Mexico, 2015.

[2] EIA, "EIA/ARI World Shale Gas and Shale Oil Resource Assessment," EIA, Arlington, 2013.

[3] Oxford Business Group, "Argentina Doubles Down On Shale Gas And Renewables," 2017. [Online]. Available: oilprice.com/Energy/Natural-Gas/Argentina-Doubles-

Down-Shale-Gas-And-Renewables.html. [Accessed 15/9/17].

[4] E. Leite and A. Sobreira, "YPF Sociedad Anonima. Why Argentina should not kill Vaca Muerta," Credit Suisse, 2012.

[5] I. Gomes and R. Brandt, "Unconventional Gas in Argentina: Will it become a game changer?," Oxford Institute for Energy Studies, Oxford, 2016.

[6] IMF, "Argentina," International Monetary Fund, Washington, D.C., 2017.

[7] A. Askenazi, P. Biscayart, M. Cáneva, S. Montenegro, M. Moreno and YPF SA, "Analogía entre la Formación Vaca Muerta y Shale Gas/Oil Plays de EEUU," SPE International, 2013.

[8] INDEC, "Precios y cantidades del comercio exterior," 2017. [Online]. Available: www.indec.gob.ar/nivel4_default.asp?id_tema_1 $=3$ \&id_tema_2=2\&id_tema_3=41. [Accesse-d 2101 2018].

[9] G. Sanagua, "Pre-Documento: Matriz Energética," Tucumán, 2017.

[10] BP PLC., "BP Statistical Review of World Energy," BP PLC., London, 2017.

[11] Ministerio de Energía y Minería, "Ministerio de Energía y Minería. Presidencia de la Nación," 2017. Online]. Available: www.energia.gob.ar/contenidos/verpagina.php?idpa gina=3271. [Accessed 2101 2018].

[12] D. Hough and C. Barton, "Oil prices," House of Commons, 2016.

[13] A. Economou, B. Fattouh, P. Agnolucci and V. De Lipsis, "Oil Price Paths in 2017: Is a Sustained Recovery of the Oil Price Looming?" The Oxford Institute for Energy Studies, Oxford, 2017.

[14] F. Aringoli, "Río Negro," 2017. [Online]. Available: www.rionegro.com.ar/energia/cambia-el-mapa-de-loscombustibles-HM3619810. [Accessed 0210 2017].

[15] M. Weissel and L. Monti, "Primeros cuatro años del desarrollo de Vaca Muerta. El valor de la historia," Desafíos Y-TEC, vol. 9, pp. 16-23, 2016.

[16] D. E. Sierra, "Developing a Vaca Muerta Shale Play: An Economic Assessment Approach," The University of Texas at Austin, Austin, 2016. Page 10 of 10

[17] Arpel, "Oportunidades para el desarrollo de petróleo y gas no convencional en América Latina y el Caribe," Arpel, 2016.

[18] IAPG, “Análisis y Proyección de Impactos Económicos Esperados del Desarrollo de los Hidrocarburos No Convencionales en Argentina," IAPG, 2014.

[19] H. Giampaoli and A. Gagliano, "Vaca Muerta: balance de siete años de desarrollo," Petrotecnia, vol. 4, pp. 90-100, 2017.

[20] T. Bielenis Villanueva, "Vaca Muerta. Improving Well Performance and Attracting New Investment," Oil \& Gas Financial Journal, vol. 14, no. 9, pp. 14-15, 2017.

[21] H. Letcher and J. Strada, "Vaca Muerta y el "éxito" de la inversión," Centro de Economía Política Argentina, 2017.

[22] C. Vale Piana, "Estadísticas Petroleras de Vaca Muerta Septiembre 2017," Rumbo Energético, 2017. 